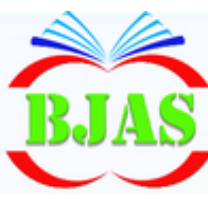

ISSN $1814-5868$
Available online at http://bjas.bajas.edu.iq

https://doi.org/10.37077/25200860.2020.33.2.13

College of Agriculture, University of Basrah
Basrah Journal of Agricultural Sciences

E-ISSN: 2520-0860

\title{
Monitoring and Management of Date Palm Borers by Using Light Traps
}

\section{Aqeel Alyousuf $^{1 *}$, Ali D. Shaaban ${ }^{2}$, Mohammed M. Alderawii ${ }^{3}$ \& Huda M. Alsaadie ${ }^{3}$}

${ }^{1}$ Department of Plant Protection, College of Agriculture, University of Basrah, Iraq.

${ }^{2}$ Department of Biology, College of Qurnah for Education, University of Basrah, Iraq.

${ }^{3}$ Basrah Department of Plant Protection, Iraqi Ministry of Agriculture, Basrah, Iraq.

*Correspondence, author email: Aqeel.alyousuf@okstate.edu

Received 2 ${ }^{\text {nd }}$ July 2020; Accepted 22 September 2020; Available online 21 October 2020

\begin{abstract}
Date palm borers become a serious threat to date palm plantations in Iraq, which required management program to suppress their population by using different methods; one of them is the light traps which disseminated in Basrah province. The objective of this trial is to evaluate the effectiveness of light traps as a part of pest management tool. In three years monitoring of coleopteran adults, rhinoceros beetles Oryctes spp. and longhorn date palm borer Jebusaea hammerschmidtii infesting the date palm Phoenix dactylifera were reported by using light traps in different regions of Basrah, Iraq. Due to the result of the abundance of the borers, Oryctes spp. were the most dominant and most important causing severe damage for the date palm. Four species of Oryctes $(O$. agamemnon, O. elegans, $O$. sahariensis and $O$. sinaicus) were recorded in Basrah date palm orchards; the seasonal activity of the species was between April and May, reaching the peaks during summer, and the populations decreased gradually till December. The overall sex ratios of all species of Oryctes spp. were male-biased except $O$. elegans, which had the sex ratio of 1.13 female: 1 male. Results revealed that the light traps exhibit an effective control method to suppress the adult borer's population and as a physical control and monitoring tool of date palm stem borers.
\end{abstract}

Keywords: Date palm, Coleoptera, Light traps, Monitoring Oryctes spp.

\section{Introduction}

Date Palm (Phoenix dactylifera L.) is considered one of the most economic fruit trees in Iraq and other countries of the Middle East and North Africa (Hazzouri et al., 2015; Khierallah et al., 2015). In Iraq, harvested area of dates was 168.86 .000 ha in 2018 (Statista, 2020) with total date palms of 17036560 trees. The production of all cultivars was 639315 tons in a yield average of $63.7 \mathrm{Kg} \cdot$ palm $^{-1}$ in 2019. In Basra province, the total palm trees were 1203121 with productivity per palm average of 41.2
Kg.palm ${ }^{-1}$ in 2019 (CSO, 2020). Palm trees are subjected to infest with different disease and pests (Alyouif and Mazeal, 2008; AlDosary, 2010; Elshafie et al., 2017). Palm borers, the longhorn date palm stem borer Jebusaea hammerschmidtii (Coleoptera: Cerambycidae) and Rhinoceros beetle Oryctes spp. (Coleoptera: Scarabaeidae) have been recognized as serious palm pests (Rochat et al., 2004; Al-Jboory , 2007; Ehsine et al., 2014; Bedford et al., 2015; Khalaf \& Alrubiae, 2015; Khalaf et al., 2017). Oryctes species are common in many countries of the 
world (Bedford et al., 2015). Oryctes rhinoceros is the most common palm borer species in Malaysia and many other countries of the world (Buxton, 1920; Bedford, 1980; Gnanasegaram et al., 2011). O. elegans infest palms in Iran and Saudi Arabia (Rochat et al., 2004; Al-Deghairi, 2007; Payandeh \& Dehghan, 2010), while O. agamemnon was recorded in Tunisia (Soltani et al., 2008; Ehsine et al., 2014), and in UAE (Al-Deeb et al., 2012).

In Iraq, O. elegans beetles were firstly recorded infesting date palms, and their rates reached $80-90 \%$ in some orchards (Hussain, 1963; Al-Kawaga, 1999; Khalaf \& Alrubiae, 2015; Khierallah et al., 2015). However, the other species $O$. agamemnon, $O$. sinaicus and O. sahariensis were recorded recently (Khalaf et al., 2013; Al-Jamali \& Al-Kariti, 2019; Augul \& Al-Saffar, 2019). Many Oryctes species infest the coconut, oil and date palm trees worldwide causing economic losses (Bedford, 2013); for example, O. rhinoceros caused a loss of $10 \%$ of the 1.796 million hectares of coconut trees in India (Gopal et al., 2001). Larvae and the adults of Rhinoceros beetles infest the date palm's stem and feed on dead and living tissues and they can cause severe damage when attacking the aerial root system leading to unexpected collapse of infested palms (Soltani et al., 2008). The adults of fruit stalk borer $O$. elegans feed on the bases of frond and the fruit-stalk in fruitful palm trees (Al-Jboory, 2007; Khalaf \& Naher, 2010); while Root borer $O$. agamemnon may change feeding behavior from a stem borer to a root borer due to egg laying activity, drought occurrence, or a food shortage, and the injury is mostly severe when the new short palms are infested (Soltani et al., 2008).

Indirect damage of the adult and larval feeding is the attracting of the other pests such as Red Palm Weevil (RPW) to lay eggs on the in the bores in the area which occupied by RPW (Al-Ayedh \& Al Dhafer, 2015). Oryctes spp. adults appear from May to October, with highest activity during August in Karbala Province, Iraq (Al-Jamali \& Al-Kariti, 2019). The presence of a large number of females of the species $O$. agamemnon indicating of the laying of a large number of eggs and this leads to major damage by larvae and adults (Soltani et al., 2008).

Light traps are common sampling technique for monitoring of the nocturnal insects (Sheikh et al., 2016); Light trap has been used as physical control method and monitoring tool of date palm stem's borers (Al-Deeb et al., 2012; Khalaf et al., 2017; AlJamali \& Al-Kariti, 2019). Understanding the population density of beetles is important for developing integrated management program (Wakil et al., 2015). In this study, date palm borers were monitored for 3 years by using light traps to detect the population densities and seasonal abundances of Oryctes spp. and Jebusaea hammerschmidtii in Basrah province.

The main objective was to determine which species of the borers is the most dominant in different places of Basrah. The second objective focused on determining the efficacy of light traps grid on management of the population densities of Oryctes spp. in Basrah.

\section{Materials \& Methods}

\section{Site description}

This study was conducted in Basrah province, Iraq. The plantation of Basrah varied based on the regions which have different ecosystems, the southern, eastern, and northern which separated into the desert and sedimentary ecosystems. The southern, the eastern and sedimentary area of the northern region are commercial plantations for date palm. More 
than one million and two hundred thousand of palms are planted in the province which was selected for this study because large number of the trees are infested with different borers.

\section{Date palm borers sampling procedure}

Sampling and monitoring study were conducted to assess date palm borer's abundance from 2016 to 2018 in 18 randomly selected date palm orchards distributed across Basrah by using 18 light traps. The traps are part of light-traps-grid (120 Magna light traps, Russell IPM Company, UK, Fig. 1) which supplied with solar-energy lamp of wave's length $350-420 \mathrm{~nm}$; the traps provided by Iraqi Ministry of Agriculture in 2015 were used to monitor date palms borers. In this study, the area of each selected orchard was at least 1 hectare composed of 140 to 160 palms. Each trap was checked biweekly and the number of beetles at each light trap per orchard were reported. Then, the adults were taken for identification and sexed based on the keys prepared by Al-Jassany \& Al-Saedy (2019). The numbers of captured males and females of Oryctes spp. were counted at each sampling event. Some of the adult specimens were sent to the Natural History Museum, University of Baghdad for identification.

\section{Statistical analysis}

The geographical distribution, relative abundance and seasonal activity of the captured date palm borers (Rhinoceros beetles and longhorn date palm stem borers) and the most abundant borers (Oryctes spp.) infested date palms were analysed for the monitoring studies. In the second analysis, the study of efficacy of light traps grid disseminated across Basrah province was tested. For both analyses, the population densities of borers were tested using analysis of variance (ANOVA) and means were compared using a Least Significant Difference (LSD) test at $\mathrm{P} \leq$ 0.05 . The analysis of the sex ratio of Oryctes spp. was determined with $\chi^{2}$ test by using $\mathrm{R}$ program (R Core Team, 2019).

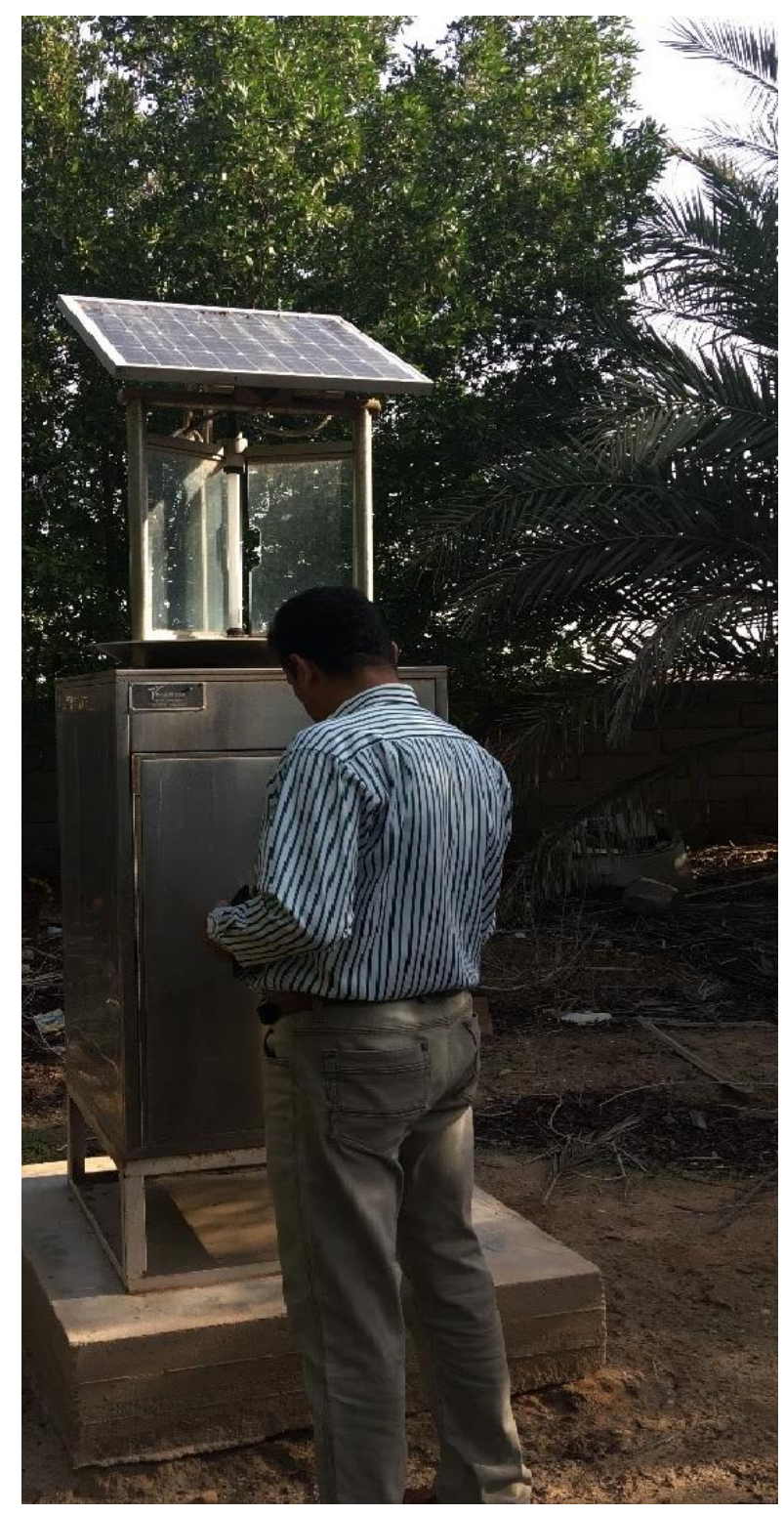

Fig. (1): Light trap which used in the sampling and monitoring study of date palm borers in Basrah province, 2016-2018.

\section{Results \& Discussion}

In 2016-2018, a total of 1512 Rhinoceros beetles Oryctes spp. belonging to four species and 147 longhorn date palm stem borers $J$. hammerschmidtii were captured by the light traps in all the regions of province of Basrah. The results of distribution of the date palm borers indicated that there were no significant 
differences in the population densities Oryctes spp. and $J$. hammerschmidtii among the regions $(F=0.373, P<0.69 ; F=3.091$ and $P$ $<0.0506$ respectively; Table 1); Oryctes spp. were the most dominant with approximately $91 \%$ of entire abundance compared with $J$. hammerschmidtii with approximately $9 \%$ of the entire abundance $(F=35.53, P<0.00000$, Fig. 2). Rhinoceros beetles were active from April to November with peak activity from July to September; however, $J$. hammerschmidtii were active from May to September with peak activity in July $(F=$ 4.836, $P<0.000137 ; F=3.521, P<0.00238$;
Table 2). The results of the number of date palm borers trapped by the light traps varied among the years (Table 3); the highest population of Oryctes spp. was 22.35 beetles.trap $^{-1}$ in 2017 , then the population reduced to 7.81 beetles.trap ${ }^{-1}$ in 2018 ( $F=$ 2.093, $P<0.152)$. There was no significant differences among the populations of longhorn date palm stem borer during the 3years of monitoring program; the highest population was 2.65 borers trap in 2017, and the densities decreased to 0.00 borers in 2018 $(F=0.824, P<0.366)$.

Table (1): Distribution of the date palm borers in Basrah during 2016-2018.

\begin{tabular}{ccccccc}
\hline \multirow{2}{*}{ Region } & \multicolumn{5}{c}{ No. of date palm borers per light trap, 2016-2018 } \\
\cline { 2 - 6 } & \multicolumn{3}{c}{ J. hammerschmidtii } & \multicolumn{4}{c}{ Oryctes spp. } \\
\cline { 2 - 6 } & Total & Mean & $(\mathrm{SE})$ & Total & Mean & $(\mathrm{SE})$ \\
\hline Southern & 88 & $4.89^{\mathrm{a}}$ & 1.79 & 231 & $12.83^{\mathrm{a}}$ & 3.58 \\
\hline Eastern & 12 & $0.88^{\mathrm{a}}$ & 0.26 & 236 & $16.79^{\mathrm{a}}$ & 4.33 \\
\hline Northern & 47 & $0.82^{\mathrm{a}}$ & 0.48 & 1041 & $18.33^{\mathrm{a}}$ & 3.10 \\
\hline
\end{tabular}

Each population was separately statically analyzed; Mean values followed by different lowercase letters are significantly different $($ LSD test, $\mathrm{P} \leq 0.05) ; \mathrm{SE}=$ Standard Error.

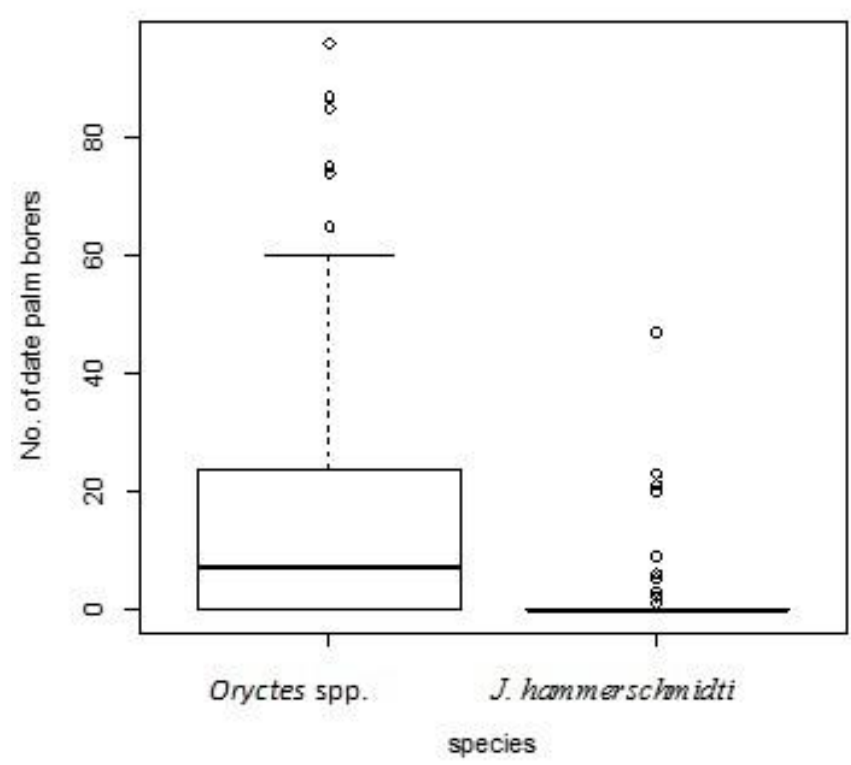

Fig. (2): The relative abundance of the date palm borers in Basrah during 2016-2018. 
Alyousuf et al. / Basrah J. Agric. Sci., 33(2): 147-157, 2020

Table (2): Seasonal activity of the date palm borers in Basrah during 2016-2018.

\begin{tabular}{ccccc}
\hline \multirow{2}{*}{ Month } & \multicolumn{4}{c}{ No. of date palm borers per light trap } \\
\cline { 2 - 5 } & \multicolumn{3}{c}{ J. hammerschmidtii } & \multicolumn{2}{c}{ Oryctes spp. } \\
\cline { 2 - 5 } & Mean & (SE) & Mean & (SE) \\
\hline April & $0.00^{\mathrm{b}}$ & 0.00 & $0.50^{\mathrm{b}}$ & 0.33 \\
\hline May & $0.90^{\mathrm{b}}$ & 0.67 & $18.20^{\mathrm{ab}}$ & 4.81 \\
\hline June & $2.46^{\mathrm{ab}}$ & 1.51 & $13.00^{\mathrm{ab}}$ & 2.94 \\
\hline July & $10.33^{\mathrm{a}}$ & 3.82 & $33.33^{\mathrm{a}}$ & 7.56 \\
\hline August & $1.67^{\mathrm{ab}}$ & 0.61 & $33.50^{\mathrm{a}}$ & 6.84 \\
\hline September & $0.30^{\mathrm{b}}$ & 0.16 & $32.40^{\mathrm{a}}$ & 8.32 \\
\hline October & $0.00^{\mathrm{b}}$ & 0.00 & $24.25^{\mathrm{a}}$ & 4.10 \\
\hline November & $0.00^{\mathrm{b}}$ & 0.00 & $1.91^{\mathrm{b}}$ & 1.20
\end{tabular}

Each population was separately statically analysed; Mean values followed by different lowercase letters are significantly different (LSD test, $\mathrm{P} \leq 0.05$ ); $\mathrm{SE}=$ standard Error.

Table (3): Effect of light traps on the population densities of date palm bores.

\begin{tabular}{|c|c|c|c|c|}
\hline \multirow{3}{*}{ Year } & \multicolumn{4}{|c|}{ No. of date palm borers per light trap } \\
\hline & \multicolumn{2}{|c|}{ J. hammerschmidtii } & \multicolumn{2}{|c|}{ Oryctes spp. } \\
\hline & Mean & $(\mathrm{SE})$ & Mean & $(\mathrm{SE})$ \\
\hline 2016 & $0.82^{\mathrm{a}}$ & 0.39 & $13.27^{\mathrm{ab}}$ & 2.64 \\
\hline 2017 & $2.65^{\mathrm{a}}$ & 1.17 & $22.35^{\mathrm{a}}$ & 3.88 \\
\hline 2018 & $0.00^{\mathrm{a}}$ & 0.00 & $7.81^{\mathrm{b}}$ & 2.05 \\
\hline
\end{tabular}

Each population was separately statically analysed; Mean values followed by different lowercase letters are significantly different (LSD test, $\mathrm{P} \leq 0.05$ ); $\mathrm{SE}=$ Standard Error.

Four species of Oryctes spp. (O. agamemnon, O. elegans, O. sahariensis and O. sinaicus; Fig. 3) were recorded associated with date palms in Basra, the results of table 4 showed that all the species of Oryctes spp. equally (non-significantly) distributed over the Basrah regions (northern, eastern and southern) $(F=1.394, P<0.254 ; F=0.095, P$ $<0.91 ; F=0.331, P<0.719 ; F=3.919, P<$ 0.0509 respectively). Numerically, the population densities varied among the species; $O$. agamemnon was the most dominant (approximately $0.34 \%$ of entire abundance), and $O$. elegans was the most second abundant (approximately $0.24 \%$ of entire abundance); whereas $O$. sinaicus had the less abundance (approximately 19\% of the entire abundance) $(F=1.636, P<0.181$; Fig. 4).



Fig. (3): Oryctes spp. collected from in Basrah between 2016-2018. 
Alyousuf et al. / Basrah J. Agric. Sci., 33(2): 147-157, 2020

Table (4): Distribution of Oryctes spp. in Basrah, 2016-2018.

\begin{tabular}{|c|c|c|c|c|c|c|c|c|}
\hline \multirow{3}{*}{ Region } & \multicolumn{8}{|c|}{ No. Oryctes spp. per light trap, 2016-2018 } \\
\hline & \multicolumn{2}{|c|}{ O. agamemnon } & \multicolumn{2}{|c|}{ O. elegans } & \multicolumn{2}{|c|}{ O. sahariensis } & \multicolumn{2}{|c|}{ O. sinaicus } \\
\hline & Mean & (SE) & Mean & (SE) & Mean & (SE) & Mean & (SE) \\
\hline Sol & $2.22^{\mathrm{a}}$ & 0.72 & $4.56^{\mathrm{a}}$ & 1.17 & $1.43^{\mathrm{a}}$ & 0.75 & $1.30^{\mathrm{a}}$ & 0.63 \\
\hline & $5.79^{\mathrm{a}}$ & 2.11 & $3.57^{\mathrm{a}}$ & 0.82 & $2.88^{\mathrm{a}}$ & 1.24 & $1.12^{\mathrm{a}}$ & 0.01 \\
\hline Northern & $6.89^{\mathrm{a}}$ & 1.50 & $3.95^{\mathrm{a}}$ & 0.91 & $2.62^{\mathrm{a}}$ & 0.82 & $2.46^{\mathrm{a}}$ & 0.90 \\
\hline
\end{tabular}

Each species population was separately statically analysed; Mean values followed by different lowercase letters are significantly different (LSD test, $\mathrm{P} \leq 0.05$ ); $\mathrm{SE}=$ Standard Error



Fig. (4): The relative abundance of Oryctes spp. in Basrah during 2016-2018.

The monthly catches of Oryctes spp. (Table 5) showed that $O$. agamemnon beetles appeared in May ( 8.40 beetles.trap ${ }^{-1}$ monthly) and the population increased reaching the peak (14.20 beetles/ trap/ month) in
September $(F=3.663, P<0.00175)$. Also, $O$. elegans, the second dominant population, emerged in May (6.00 beetles.trap ${ }^{-1}$ monthly) with peak activity (7.00 and 7.42 beetles.trap ${ }^{-1}$ monthly) in September and October respectively $(F=2.554, P<0.0199)$.

Table (5): Seasonal activity of Oryctes spp. in Basrah during 2016-2018.

\begin{tabular}{|c|c|c|c|c|c|c|c|c|}
\hline \multirow{3}{*}{ Month } & \multicolumn{8}{|c|}{ No. Oryctes spp. per light trap } \\
\hline & \multicolumn{2}{|c|}{ O. agamemnon } & \multicolumn{2}{|c|}{ O. elegans } & \multicolumn{2}{|c|}{ O. sahariensis } & \multicolumn{2}{|c|}{ O. sinaicus } \\
\hline & Mean & (SE) & Mean & $(\mathrm{SE})$ & Mean & (SE) & Mean & $(\mathrm{SE})$ \\
\hline Apr & $0.00^{b}$ & 0.00 & $0.00^{\mathrm{b}}$ & 0.00 & $0.25^{\mathrm{ab}}$ & 0.17 & $0.25^{\mathrm{ab}}$ & 0.71 \\
\hline May & $8.40^{\mathrm{ab}}$ & 2.13 & $6.00^{\mathrm{a}}$ & 2.18 & $1.60^{\mathrm{ab}}$ & 0.58 & $2.20^{\mathrm{ab}}$ & 0.48 \\
\hline June & $3.46^{\mathrm{ab}}$ & 1.11 & $2.92^{\mathrm{ab}}$ & 0.55 & $3.077^{\mathrm{ab}}$ & 1.02 & $3.54^{\mathrm{ab}}$ & 1.70 \\
\hline Jul & $10.67^{\mathrm{ab}}$ & 3.89 & $6.78^{\mathrm{a}}$ & 1.80 & $7.00^{\mathrm{ab}}$ & 2.02 & $8.89^{\mathrm{a}}$ & 2.87 \\
\hline Aug & $13.67^{\mathrm{ab}}$ & 2.88 & $3.17^{\mathrm{ab}}$ & 1.61 & $10.67^{a}$ & 3.31 & $6.00^{\mathrm{ab}}$ & 1.55 \\
\hline Sep & $14.20^{\mathrm{a}}$ & 4.17 & $7.00^{\mathrm{a}}$ & 2.21 & $10.20^{\mathrm{a}}$ & 0.73 & $1.00^{\mathrm{ab}}$ & 0.75 \\
\hline Oct & $4.33^{\mathrm{ab}}$ & 1.35 & $7.42^{\mathrm{a}}$ & 1.39 & $5.08^{\mathrm{ab}}$ & 1.58 & $7.42^{\mathrm{a}}$ & 2.10 \\
\hline Nov & $0.62^{\mathrm{b}}$ & 0.62 & $0.95^{\mathrm{b}}$ & 1.03 & $0.19^{\mathrm{b}}$ & 0.20 & $0.14^{\mathrm{b}}$ & 0.15 \\
\hline
\end{tabular}

Each species population was separately statically analyzed; Mean values followed by different lowercase letters are significantly different (LSD test, $\mathrm{P} \leq 0.05)$; $\mathrm{SE}=$ Standard Error. 
Both $O$. sahariensis and $O$. sinaicus emerged in April with average of population densities 0.25 beetles.trap ${ }^{-1}$ monthly and the densities increased to 10.67 beetles.trap ${ }^{-1}$ on August and 8.89 beetles.trap ${ }^{-1}$ on July respectively $(F=3.655, P<0.0017, F=$ $3.337, P<0.00357$ respectively).

The numbers of annual captured males of Oryctes spp. were greater than that of the trapped females except $O$. elegans (Table 6).
The overall sex ratio of the captured of $O$. sahariensis, $O$. sinaicus and $O$. gamemnon were male-biased which were 1:1.46 (143 females: 209 males; $\left.\chi^{2}=578.79, p<0.0000\right)$, 1:1.32 (124 females: 164 males; $\chi^{2}=508.51$, $p<0.0000$ ) and 1:1.3 (223 females: 291 males; $\left.\chi^{2}=657.02, p<0.0000\right)$ respectively, however, the sex ratio of $O$. elegans was close to the predictive sex ratio 1:1 which was 1.13:1 (190 females: 168 males; $\chi^{2}=381.35, p$ $<0.0000)$.

Table (6): Sex ratio of Oryctes spp. in Basrah during 2016-2018.

\begin{tabular}{ccccccccc}
\hline & \multicolumn{7}{c}{ No. Oryctes spp. per light trap } \\
\cline { 2 - 10 } Year & O. sahariensis & \multicolumn{2}{c}{ O. sinaicus } & O. elegans & \multicolumn{2}{c}{ O. gamemnon } \\
\cline { 2 - 10 } & Female & Male & Female & Male & Female & Male & Female & Male \\
\hline 2016 & 26 & 21 & 15 & 13 & 23 & 13 & 24 & 11 \\
\hline 2017 & 109 & 177 & 75 & 113 & 124 & 120 & 183 & 261 \\
\hline 2018 & 8 & 11 & 34 & 38 & 43 & 35 & 16 & 19 \\
\hline Total & 143 & 209 & 124 & 164 & 190 & 168 & 223 & 291 \\
\hline F:M & $1: 1.46$ & $1: 1.32$ & $1.13: 1$ & $1: 1.3$ \\
\hline
\end{tabular}

The efficiency of the light traps on the population of the Oryctes spp. (Table 7) indicated the densities of the beetles were decreased over the years, and the results showed that there were significant differences among the populations of the O. agamemnon and $O$. sahariensis captured by the light traps throughout the period of monitoring program; their highest population were 8.54 and 5.50 beetles.trap ${ }^{-1}$ in 2017 respectively, then decreased to 1.35 and 0.73 beetles.trap ${ }^{-1}$ in 2018 respectively $(F=2.037, P<0.0157, F=$ $3.919, P<0.0509$ respectively). However, the populations of $O$. elegans and $O$. sinaicus were 4.69 and 3.63 beetles per trap in 2017 respectively, then their densities have been decreased to 2.96 and 2.77 beetles.trap ${ }^{-1}$ in 2018 respectively $(F=0.247, P<0.621, F=$ $0.013, P<0.909$ respectively).
Three years monitoring of borers pests infesting the commercial plantations for date palm by using light traps grid disseminated across different regions of Basrah province showed many coleopteran adults were captured from April to November annually. Rhinoceros beetles Oryctes spp. and longhorn date palm stem borers $J$. hammerschmidtii were the most common dangerous borers reported.

The results of distribution of the date palm borers indicated that both of the borers have been distributed in all regions where date palm plantation are grown. Oryctes spp. were very high abundance compared to $J$. hammerschmidtii, and depending on these results, it thought that Oryctes spp. are responsible for the severe damage on the date palms

of

Basrah. 
Alyousuf et al. / Basrah J. Agric. Sci., 33(2): 147-157, 2020

Table (7): Effect of light traps on the population densities of Oryctes spp.

\begin{tabular}{lcccccccc}
\hline & \multicolumn{7}{c}{ No. Oryctes spp. per light trap } \\
\cline { 2 - 9 } Year & \multicolumn{7}{c}{ O. gamemnon } & \multicolumn{7}{c}{ O. elegans } & O. sahariensis & \multicolumn{2}{c}{ O.sinaicus } \\
& Mean & (SE) & Mean & (SE) & Mean & (SE) & Mean & $(\mathrm{SE})$ \\
& & & & & & & & \\
\hline 2016 & $3.18^{\mathrm{ab}}$ & 0.70 & $3.27^{\mathrm{a}}$ & 1.00 & $4.27^{\mathrm{ab}}$ & 1.07 & $2.55^{\mathrm{a}}$ & 0.44 \\
\hline 2017 & $8.54^{\mathrm{a}}$ & 1.80 & $4.69^{\mathrm{a}}$ & 1.03 & $5.50^{\mathrm{a}}$ & 1.30 & $3.62^{\mathrm{a}}$ & 1.03 \\
\hline 2018 & $1.35^{\mathrm{b}}$ & 0.58 & $2.96^{\mathrm{a}}$ & 0.74 & $0.73^{\mathrm{b}}$ & 0.20 & $2.77^{\mathrm{a}}$ & 1.01 \\
\hline
\end{tabular}

Each species population was separately statically analysed; Mean values followed by different lowercase letters are significantly different (LSD test, $\mathrm{P} \leq 0.05) ; \mathrm{SE}=$ Standard Error

The results of management of the date palm borers showed that the light traps were effective methods to control of Rhinoceros beetles due to the decreasing of high population densities of the Oryctes spp. between 2016 and 2018, compared to the nonsignificant effect on the numbers of longhorn stem borers which were very low during the studying period. For that reason, the study focused on the monitoring and management of Oryctes spp.

In this part of the study, four species of Rhinoceros beetle ( $O$. agamemnon, $O$. elegans, $O$. sahariensis and $O$. sinaicus) were recorded in all the regions of Basrah. Also, $O$. sahriensis de Mire was recorded for the first time in Basrah province. All Oryctes spp., which recorded in Basrah were found in southern and eastern Iraq (Al-Jassany \& AlSaedy, 2019). Also, it was noticed that $O$. agamemnon was the most dominant and $O$. elegans was the most second abundant, while the population densities of $O$. elegans was the highest in the other provinces (Al-Jassany \& Al-Saedy, 2019).

The seasonal activity of Oryctes spp. revealed to the variation of the population densities of captured beetles monthly, and showed that the adults of Oryctes spp. appeared between April and May and reached their peaks during the summer, and their populations decreased gradually reaching lower population levels in December. (Khalaf et al., 2010) found that the density of $O$. elegans trapped by light traps (Russel IPM Company) was 28.5 beetles.trap ${ }^{-1}$ from July to October, while the population peak was 37 beetles / traps during September. The sexual ratios of the species of Oryctes were malebiased except $O$. elegans. Al-Jassany \& AlSaedy (2019) found that sexual ratio of $O$. elegans, and $O$. sinaicus were female-biased (1 male: 1.44 females and 1 male: 1.49 females) respectively in the middle of Iraq; Soltani (2014) indicated that the sexual ratio of the O. agamemnon arabicus was (1 male: 2 female) in Tunisia.

The light traps can be considered as one of the effective means to control the insect in palm due to the high efficiency of attracting a large number of Oryctes spp. beetles. The descending of population densities of the borers were shown over the monitoring years since the light traps were settled in Basrah province due to the sequential trapping of beetles over the years across the regions; Khalaf et al. (2012) indicated that the population density was reduced from 6 to 1.8 larvae / palm trees because of the trapping of their adults in the middle of Iraq. The 


\section{Alyousuf et al. / Basrah J. Agric. Sci., 33(2): 147-157, 2020}

successful IPM programs are effectively developed depending on ecological-friendly techniques for reliable monitoring plans; light traps is one of the most important techniques in the palm pest management program that used to reduce the population density of borers on palm trees (Al-Deeb et al., 2012; Khalaf et al., 2012).

\section{Conclusion}

To conclude to my results, Rhinoceros beetles Oryctes spp., are responsible for the severe damage of date palms in Basrah showing high abundance compared to J. hammerschmidtii. The populations of the borers $(O$. agamemnon, O. elegans, $O$. sahariensis and O. sinaicus), which were active between April and May, descended over the monitoring years since the light traps were settled in Basrah province due to the sequential trapping of beetles over the years. Depending on management record, light traps (ecological-friendly technique) are effective method as one of the physical control tactics.

\section{Acknowledgment}

The authors thank the staff of Basrah department of Plant Protection, Ministry of Agriculture, Iraq, who facilitate conducting this research using the light traps grid across the province.

\section{Conflicts of interest}

The authors declare that they have no conflict of interests.

ORCID: A. Alyousuf: https://orcid.org/00000002-7352-0168

\section{References}

Al-Ayedh, H., \& Al Dhafer, H. (2015). Does Oryctes elegans (Coleoptera: Scarabaeidae) abundance determine future abundance of Rhynchophorus ferrugineus (Coleoptera: Rhynchophoridae) in the date palms of Saudi Arabia?. African Entomology., 23, 43-47. https://doi.10.4001/003.023.0102
Al-Deeb, M., Mahmoud, S., \& Sharif, E. (2012). Use of light traps and differing light color to investigate seasonal abundance of the date palm pest, Oryctes agamemnon arabicus (Coleoptera: Scarabaeidae). Journal of Economic Entomology, 105, 2062-2067. https://doi.10.1603/EC12141

Al-Deghairi, M. (2007). Seasonal fluctuation of the date palm fruit Sstalk Bborer, Oryctes elegans Prell (Coleoptera: Scarabaeidae), in date palm plantations in Al-Qassim region, Saudi Arabia. Journal Agriculture and Marine Science, 12, 67-70. https://doi.10.24200/jams.vol12iss0pp67-70

Al- Dosary, N. (2010). Evaluate efficiency of some insecticides and sticker color traps to protected date palm fruits infested by dust mite Oligonychus afrasiaticus (mcgregor) and lesser date moth Batrachedra amydraula (merck). Basrah Journal of Agricultural Sciences, 23(1): 162-184. (in Arabic)

Al-Jamali, A. A.-S., \& Al-Kariti, O. A. H. (2019). Study the situation of palm borers in some orchards of Karbala by using different kind of traps. Journal of Kerbala for Agricultural Sciences, 2(3), 28-38.

https://jkas.uokerbala.edu.iq/article_160372.html

Al-Jassany, R. F., \& Al-Saedy, H. M. (2019). Survey and identification of Oryctes beetle species (Coleoptera: Dynastidae) and determination of their relative occurrence in Iraq. Arab Journal of Plant Protection, 37, 22-30. http://dx.doi.org/10.22268/AJPP-037.1.022030

Al-Jboory, I. J. (2007). Survey and identification of the biotic factors in the date palm environment and its application for designing IPM-Program of date palm pests in Iraq. University of Aden Journal of Natural and Applied Sciences, 11, 423-457.

Al-Kawaga, A. H. (1999). Control of Oryctes elegans by cultural, biological and chemical means. Iraqi Journal of Agriculture Science, 4, 20-31.

Alyouif, A. A. and Mazeal, M. M (2008). Study of Lesser Date Moth infestation and economic losses on Date palm cvs. Sayer and Halawy. Basrah Journal For Date Palm Research, 7(2): 82-82. (In Arabic).

Augul, R. S., \& Al-Saffar, H. H. (2019). Survey with checklist of the invasive insects to Iraq. Bulletin of the Iraq Natural History Museum, 15, 343-361. https://doi.org/10.26842/binhm.7.2019.15.3.0343 


\section{Alyousuf et al. / Basrah J. Agric. Sci., 33(2): 147-157, 2020}

Bedford, G. O. (1980). Biology, ecology, and control of ;palm Rhinoceros beetles. Annual review of entomology, 25, 309-339. https://doi.10.1146/annurev.en.25.010180.001521

Bedford, G. O. (2013). Long-term reduction in damage by rhinoceros beetle Oryctes rhinoceros (L.)(Coleoptera: Scarabaeidae: Dynastinae) to coconut palms at Oryctes nudivirus release sites on Viti Levu, Fiji. African Journal of Agricultural Research, $\quad 8, \quad 6422-6425$. https://doi.10.5897/AJAR2013.7013

Bedford, G. O., Al-Deeb, M. A., Khalaf, M. Z., Mohammadpour, K., \& Soltani, R. (2015). Dynastid Beetle Pests. In Wakil W., Romeno Faleiro, J. \& Miller, T. (Eds.), Sustainable Pest Management in Date Palm: Current Status and Emerging Challenges. Sustainability in Plant and Crop Protection. Springer, Cham, 73-108.

Buxton, P. A. (1920). Insect pests of dates and the date palm in Mesopotamia and elsewhere. Bulletin of Entomological Research, 11, 287-304. https://doi.10.1017/S0007485300044709

CSO (Central Statistics Organization) (2020). Comparison between dates production and average yield per productive palm in production stage in Iraq (2015-2019). from Central Statistical Organization, Iraq http://cosit.gov.iq/ar/agristat/agri-other-2

Ehsine, M. H., Belkadhi, M. S., \& Chaieb, M. (2014). Seasonal and nocturnal activities of the Rhinoceros Borer (Coleoptera: Scarabaeidae) in the North Saharan Oases ecosystems. Journal of Insect Science, 14, 1-5. https://doi.10.1093/jisesa/ieu118

Elshafie, H., Abdel-Banat, B., \& Al-Hajhoj, M. (2017). Arthropod pests of date palm and their management. CAB Reviews, 12, 1-18. https://doi.10.1079/PAVSNNR201712049

Gnanasegaram, M., Muhamad, R., Faridah,Q. Z., \& Tan, S. (2011). Genetic variation studies in Oryctes rhinoceros (L.) (Coleoptera: Scarabaeidae) from oil palm plantations using random amplified microsatellite (RAMs) markers. African Journal of Biotechnology, $\quad 10, \quad$ 2611-2617. https://doi.10.5897/AJB10.1537

Gopal, M., Gupta, A., Sathiamma, B., \& Nair, C. P. (2001). Control of the coconut pest Oryctes rhinoceros L. using the Oryctes virus. International
Journal of Tropical Insect Science, 21, 93-101. https://doi.10.1017/S1742758400020142

Hazzouri, K. M., Flowers, J. M., Visser, H. J., Khierallah, H. S. M., Rosas, U., Pham, G. M., \& Purugganan, M. D. (2015). Whole genome resequencing of date palms yields insights into diversification of a fruit tree crop. Nature Communications, $\quad 6, \quad 8824$. https://doi.10.1038/ncomms9824

Hussain, A. A. (1963). Notes on borers of date palms in Iraq. Bulletin of Entomological Research, 54, 345-348. https://doi.10.1017/S0007485300048835

Khalaf, M. Z., \& Alrubiae, H. F. (2015). Impact of date palm borer species in iraqi agroecosystems. Emirates Journal of Food and Agriculture, 28, 5257. https://doi.org/10.9755/2015.05.200

Khalaf, M., \& Naher, F. (2010). Population density of Oryctes elegans Prell. (Coleoptera: Scarabaeidae) on some date palm varieties in South Baghdad Orchards. Agriculture and Biology Journal of North America, $\quad 1, \quad 238-242$. https://doi.10.5251/abjna.2010.1.3.238.242

Khalaf, M. Z., Naher, F. H., \& Ali, A. (2010). Population density of Oryctes elegans Prell.(Coleoptera: Scarabaeidae) on some date palm varieties in south Baghdad Orchards. Agriculture and Biology Journal of North America, 1, 238-242. https://scihub.org/journal/abjna/volume-1-issue-3may-2010/

Khalaf, M. Z., Al-Rubeae, H. F., Al-Taweel, A. A., \& Naher, F. H. (2013). First record of Arabian Rhinoceros beetle, Oryctes agamemnon arabicus Fairmaire on date palm trees in Iraq. Agriculture and Biology Journal of North America, 4, 349-351. https://doi.10.5251/abjna.2013.4.3.349.351

Khalaf, M. Z., Alrubeai, H. F., Khudhaer, M. W., \& Abdulhusein, A. A. (2017). Ecological sound control strategies for population suppression of Date Palm Borers Oryctes spp. Journal of Agricultural Science and Technology, A 7, 18-24. https://doi.10.17265/2161-6256/2017.01.003

Khalaf, M. Z., Shbar, A. K., Naher, F. H., Jabo, N. F., Abdulalhamza, B. H., \& Sami, R. A. (2012). Activity of insect fauna during the night in the palm orchards of central Iraq. Journal of Food Science and Engineering, 2, 277-282. https://doi.10.17265/2159-5828/2012.05.005 


\section{Alyousuf et al. / Basrah J. Agric. Sci., 33(2): 147-157, 2020}

Khierallah, H., Bader, S., Ibrahim, K., \& Al-Jboory, I. (2015). Date Palm Status and Perspective in Iraq. 97-152. In: Al-Khayri, J., Jain, S., \& Johnson, D. (Eds.). Date Palm Genetic Resources and Utilization. Springer, Dordrecht,. https://doi.10.1007/978-94-017-9707-8_4

Payandeh, A., \& Dehghan, A. (2010). Demography of date palm fruit stalk borer, Oryctes elegans (Col.: Scarabeaidae), on date palm under laboratory conditions. Plant Protection Journal, 2, 255-263. https://www.sid.ir/en/journal/ViewPaper.aspx?id= 326138

Rochat, D., Mohammadpoor, K., Malosse, C., AvandFaghih, A., Lettere, M., Beauhaire, J., Morin, J-P., Pezier, A., Penou, M., \& Abdollahi, G. A. (2004). Male aggregation pheromone of Date Palm fruit stalk Borer Oryctes elegans. Journal of Chemical Ecology, 30, 387-407. https://doi.10.1023/B:JOEC.0000017984.26917.52

Sheikh, A., Bhandari, R., Thomas, M., \& Bunkar, K. (2016). Light trap and Insect sampling: An overview. International Journal of Current Research, $\quad 8(, \quad 40868-40873$. https://www.journalcra.com/sites/default/files/iss ue-pdf/18459.pdf

Soltani, R. (2014). Observations on the biology and the ecology of Oryctes agamemnon arabicus, a pest of date palm tree in Southwest Tunisia. Tunisian
Journal of Plant Protection, 9, 131-142. http://www.tjpp.tn/SiteWeb/PreviousIssues/TJPP9 -2/4Rasmi.pdf

Soltani, R., Lkbel, C., \& Habib Ben Hamouda, M. (2008). Descriptive study of damage caused by the rhinoceros beetle, Oryctes agamemnon, and its influence on date palm oases of Rjim Maatoug. Tunisia. Journal of Insect Science, 8, 1-11. https://doi.org/10.1673/031.008.5701

Statista. (2020). Harvested area of dates worldwide in 2018 , by leading country (in 1,000 hectares), FAO. Retrieved from https://www.statista.com/statistics/960426/harve sted-area-of-dates-by-leading-country-worldwide/.

R Core Team (2019). R: A Language and Environment for Statistical Computing (Version 3.5.3). R Foundation for Statistical Computing, Vienna, Austri. Retrieved from https://www.r-project.org/

Wakil, W., Faleiro, J. R., Miller, T. A., Bedford, G. O., \& Krueger, R. R. (2015). Date Palm Production and Pest Management Challenges. In Wakil, W., Faleiro, J. R., Miller, T. A. (Eds.), Sustainable Pest Management in Date Palm: Current Status and Emerging Challenges. Sustainability in Plant and Crop Protection. Springer, Cham, 1-11.

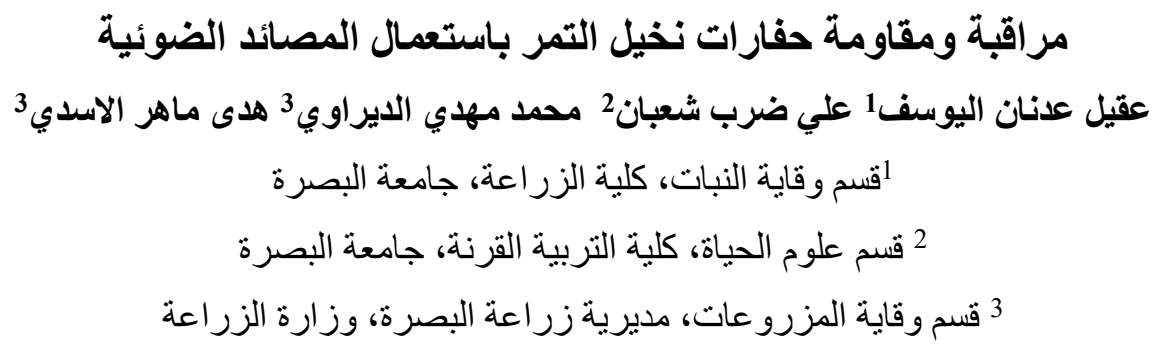

المستخلص: تم مر اقبة أنواع بالغات حفار ات عذوق النخيل وحيدة القرن .Oryctes spp وحفارات ساق نخيل ذو القرون الطويلة Jebusaea hammerschmidtii التي تصيب أشجار النخيل باستخدام المصائد الضوئية ولمدة ثلاث سنوات بـات بين

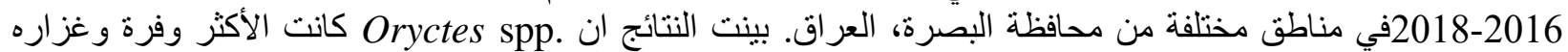





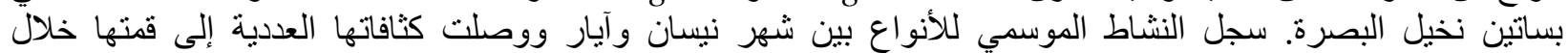


كانت هي الاعلى باستناء Oryctes spp.

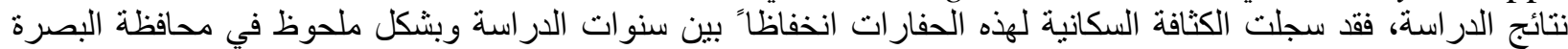
بسبب شبكة المصائد الضوئية (التقنية الصديقة للبيئة ) التي توز عت على مناطق مختلفة في المحافظة. 